\title{
Location determinants of green technological entry: evidence from European regions
}

\author{
Carlo Corradini
}

Accepted: 30 June 2017 / Published online: 30 September 2017

C) The Author(s) 2017. This article is an open access publication

\begin{abstract}
In this paper, we explore the spatial distribution and the location determinants of new green technology-based firms across European regions. Integrating insights from evolutionary economic geography and the literature on knowledge spillovers, we study the importance of new knowledge creation and the conditioning role played by regional technological relatedness in fostering combinatorial opportunities underlying the process of green technological entry. The analysis is based on a dataset covering over 900 NUTS3 regions for 15 European countries obtained merging economic data from ESPON-Eurostat and patent information from the PATSTAT-CRIOS database for the period 1996-2006. Our results show that the geographical distribution of green technological entry across European regions is not evenly distributed, offering evidence of spatial path dependence. In line with this, we find evidence of a significant role played by the characteristics of the regional innovation system. New green innovators are more likely to develop in regions defined by higher levels of technological activity underlying knowledge spillovers and more dynamism in technological entry. Moreover, our findings point to an inverted-U relationship between regional technological relatedness and green technological entry. Regions whose innovation activity is defined by cognitive proximity to environmental technologies support interactive learning and
\end{abstract}

C. Corradini $(\square)$

Aston Business School, Aston University, Aston Triangle, B4

7ET, Birmingham, UK

e-mail: c.corradini@aston.ac.uk knowledge spillovers underlying entrepreneurship in this specific area. However, too much relatedness may cause technological lock-ins and reduce the set of combinatorial opportunities.

Keywords Green entrepreneurship · NTBFs . Technological entry $\cdot$ Relatedness $\cdot$ Regional branching . Spatial path dependence

JEL classifications $\mathrm{L} 6 \cdot \mathrm{L} 26 \cdot \mathrm{O} 31 \cdot \mathrm{O} 33 \cdot \mathrm{Q} 55 \cdot \mathrm{R} 11$

\section{Introduction}

In the last decades, the increasing attention towards the relationship between novel solutions for the environmental sustainability of the economy and business activity has led to an expanding strand of research on environmental innovations and technological change (Carraro and Siniscaico 1994; Popp et al. 2010; Bansal and Hoffman 2012). Researchers have focused on the determinants of environmental innovation, mostly exploring the fundamental role of regulatory, demand and cost-saving factors (Jaffe et al. 2003; Horbach 2008; Demirel and Kesidou 2011; Kesidou and Demirel 2012). Others have looked at the importance of environmental management tools and firms' organisational capabilities, pointing to a complex relationship (Rehfeld et al. 2007; Wagner 2007; Ziegler and Nogareda 2009; Antonioli et al. 2013).

Recent studies have also started exploring the role of small and medium firms (SMEs) in the development of 
environmental innovations. The importance of this area of research is twofold. On one side, SMEs account for the majority of environmental pollution (European Commission 2010). On the other side, SMEs as well as new firms play a complementary and increasingly important role in generating technological innovations (Acs and Audretsch 1987; Rothwell, 1989; Rogers, 2004). While results on the drivers of environmental practices of SMEs and relationship between firm size and eco-innovation are still mixed (Aragón-Correa et al. 2008; Wagner 2008; Triguero et al. 2013; Hoogendoorn et al. 2015), evidence on the contribution of new innovative firms seems to suggest a more defined role of green entrepreneurship.

The few studies on green entrepreneurship have offered some initial insights, exploring technological strategies, firm-level innovation activity and alliances, albeit the majority of the work in this area is mostly centred around sustainability entrepreneurship (Hall et al. 2010; Hockerts and Wüstenhagen 2010; OECD 2011; Meyskens and Carsrud 2013). However, research on the innovation and entrepreneurship dynamics inherent to green start-ups remain largely underdeveloped. In particular, while previous research offers descriptive insights from selected regions and technologies pointing to the importance of the regional economy for the emergence of this new industry (Smith 2007; Madsen and Andersen 2010; Tanner 2015), there is limited evidence on the locational determinants of new green innovative firms.

In this paper, we aim to contribute to the literature on green entrepreneurship exploring spatial determinants of green technological entry, defined by the presence of new green companies applying for a patent for the first time. The use of patents to define innovation means our analysis cannot encompass the broad category of innovative green start-ups as indeed many companies can certainly be innovative even if they do not apply for patents. Instead, the attention is placed on the subset of technology intensive - or technology-based companies within this group. In this sense, our study can be seen as focusing on the formation of new technology-based firms (NTBFs) operating in the environmental sector.

This perspective is particularly interesting considering the limited empirical research on this specific category of new companies but also the role of new technology-based firms as important agents for the introduction of radical innovation and technological paradigm change, especially in the emergence of new industries and sectors characterised by a rapid pace of technological development (Nelson and Winter 1982; Klepper 1996; Storey and Tether 1998, Ejermo and Xiao 2014). In this sense, new green technology-based firms might play a crucial role, potentially complementary to incumbent innovators, in the sustainable transformation of industries and the development of novel environmental technologies (Hockerts and Wüstenhagen 2010; Criscuolo and Menon 2015).

Thus, we build on a theoretical framework based on evolutionary economic geography and the knowledge spillover theory of entrepreneurship (Boschma and Frenken 2006; Boschma and Martin 2010; Acs et al. 2009, 2013) to examine the importance of spatial path dependence, regional patterns of new knowledge creation and entrepreneurial dynamism for green technological entry. Moreover, we look at the non-linear relationship between technological relatedness across environmental and other technologies and combinatorial opportunities underlying the process of green technological entry.

Using a dataset obtained merging information from ESPON-Eurostat and the PATSTAT-CRIOS database for over 900 NUTS3 regions over 15 European countries in the period 1996-2006, our results offer novel evidence on the spatial distribution and the location determinants of green technological entry across European regions. We find that the distribution of green technological entry is markedly uneven across and within countries. In particular, the data indicate these location patterns are strongly defined by the innovative activity of incumbent companies in the region and the presence of technological dynamism, defined by the overall number of technological entrants. Our findings also point to an inverted-U relationship between regional technological relatedness and green technological entry. This suggests that while knowledge related to environmental technologies is important to foster learning processes and spur the process of knowledge spillover underlying new green technology-based firms in embedded spaces, diversity in the knowledge base remains essential to sustain the process of recombinant innovation that underpins their entry.

The paper is organised as follows. In Section 2, we review previous studies on location determinants of new firm creation and define a theoretical framework for green technological entry. Section 3 describes the data for this study. Section 4 presents the main variables in our model and its econometric specification. Section 5 provides descriptive information on green technological entry across European regions and a discussion of the 
regression results. In Section 6, we present the conclusions from this study.

\section{Literature review and hypotheses}

Since the seminal insights by Marshall (1890), spatial concentration and agglomeration externalities have been indicated as key drivers underlying innovation as well as economic growth, emphasising the quasi-public nature of knowledge and its propensity to spread, or spill over, leading to localised increasing returns (Nelson and Winter 1982; Romer 1990; Lucas 1993). Building on this, an expanding body of theoretical and empirical works has brought to the fore the importance of local proximity and geographic clusters in the formation of new innovative companies. This is notably reflected in the Knowledge Spillover Theory of Entrepreneurship (Acs et al. 2009, 2013). According to this theory, entrepreneurial activity can be modelled as a function of the innovative activity and the creation of new knowledge by incumbent firms and organisations (Acs et al. 2009). In particular, the uncertain and asymmetric nature of new knowledge leads to potential novel recombinations and inventions not being recognised or valued by incumbent firms. Thus, the uncommercialised knowledge generated by these firms may spill over to agents that identify technological opportunities in these residual ideas, stimulating the creation of new ventures.

In this framework, the characteristics of the spatial context play a crucial role on the emergence of new technology-based firms as these start-ups need to rely on access to ideas and technological opportunities through processes of knowledge spillovers, which are geographically localised (Jaffe et al. 1993; Maurseth and Verspagen 2002; Moreno et al. 2005; Sonn and Storper 2008). The role of regions and the importance of spatial proximity are especially significant for the development of new innovative companies, as the knowledge that characterises entrepreneurial processes is inherently more fuzzy, uncertain and difficult to codify. In this sense, interactions underlying the access and evaluation of technological opportunities are more likely to be localised and characterised by higher geographical concentration. In line with this, empirical evidence associates regions defined by higher levels of knowledge creation with higher start-up rates (Audretsch and Feldmann 1996; Audretsch and Lehmann 2005; Audretsch et al. 2006). This is further reinforced by the process of technological path dependence that defines regional innovation activities.

The importance of spatial clustering seems to play an important role for the emergence of environmental technologies and the green industry as well. Exploring different case studies across various green sectors in some European regions, previous studies provide descriptive evidence of a spatial concentration in environmental technologies and the presence of 'green clusters' of entrepreneurs in this area (Garud and Karnøe 2003; Lehmann 2006; Smith 2007). Focusing on the emergence of new green technologies, scholars have underlined the presence of complex interactions and the fluid exchange of information and knowledge across different economic agents (Mans et al. 2008; Cooke 2010; Tanner 2014). In particular, Madsen and Andersen (2010) explore the economic geography of hydrogen and fuel cell technology (H2FC) development looking at the relationship between $\mathrm{H} 2 \mathrm{FC}$ and innovative clusters, finding that regions characterised by a strong presence of $\mathrm{H} 2 \mathrm{FC}$ activity are likely to be innovative regions overall. However, evidence on whether this may equally impact the development of new green technology-based firms remains limited.

The creation of new knowledge is not sufficient to explain the patterns of green technological entry as the skills, insights and transmission of information, and ideas necessary to translate spillovers into new technology-based firms are not uniformly distributed across people and regions (Acs et al. 2009). Regions are endowed with different capabilities to identify and respond to technological opportunities (Saxenian 1990). Indeed, previous studies have shown that even after controlling for elements such as industry structure, qualification of the workforce and economic well-being, a significant part of the persistency in the rate of new firms across regions remains unexplained, pointing to the relevance of more intangible elements (Armington and Acs 2002; Beugelsdijk and Noorderhaven 2004; Fritsch and Mueller 2007). In the literature, these elements have been associated with the presence of informal institutions and untraded interdependencies defining localised associative capabilities and learning processes (Storper 1995; Cooke and Morgan 1998; Bathelt and Glückler 2003). These elements define the set of informal relational resources that underpin sharing and recombination of ideas leading to a more effective transmission of knowledge, increasing the capabilities to absorb and act upon technological opportunities defined 
by knowledge spillovers. This may result in a regional environment defined by higher technological dynamism characterised by more technological entrants. In line with this, while regions that have a higher level of knowledge stock may offer more opportunities for technological entry through the provision of knowledge spillovers, those defined by a more dynamic emergence of technological entrants may be seen as offering a more effective 'supply architecture' (Storper 1995) for the recombination of ideas and the exploitation of technological opportunities, thereby fostering green technological entry. Following these considerations, we posit the following two hypotheses:

Hypothesis 1: the level of new knowledge creation by incumbent companies exerts a positive effect on green technological entry.

Hypothesis 2: regions characterised by higher technological dynamism are more likely to foster green technological entry.

Regions do not shape the emergence of new innovators only through the provision of knowledge creation and potential spillover opportunities from incumbent firms. A significant number of studies have been devoted to the role that the underlying economic or technological structure of regions may play in the growth and technological change, and indeed technological entry. In particular, previous literature has focused on two main perspectives contrasting the degree of diversity as opposed to specialisation. Diversity may foster novel recombination of ideas through interindustry spillovers (Jacobs 1969; Corradini and De Propris 2015), while regional specialisation has been associated with reduced transaction costs leading to more effective sector-specific knowledge externalities (Marshall 1890; Glaeser et al. 1992). An intermediate perspective suggests regions may have an innovation advantage when characterised by related variety, where the degree of cognitive proximity is large enough to allow for interesting recombinations but not too large, hampering effective learning (Frenken et al. 2007; Castaldi et al. 2014).

The importance of the structure and the dynamics inherent to regional systems of innovation is strongly connected to the emerging literature on evolutionary economic geography. Unifying insights on the spatially embedded nature of knowledge spillovers and the importance of a coherent knowledge base for absorbing, sharing and recombining previous technologies (Cohen and Levinthal 1990; Nooteboom 2000; Breschi et al. 2003); this stream of research posits that regional structural change is fundamentally shaped by the degree of relatedness among the existing innovation activities (Martin and Sunley 2006; Boschma and Martin 2010; Neffke et al. 2011). In particular, technological relatedness and its inherent element of knowledge proximity affect the spatial conditions for the exchange of ideas so that the future direction of regional technological trajectories is closely related to the coherent set of previously accumulated innovative competencies. Thus, regional branching and the direction of regional technological change are not only path dependent, but also place dependent (Martin and Sunley 2006). Following this perspective, recent studies have explored the relevance of spatial path dependence offering evidence of the relationship between the development of emerging fuel cell technology and its technological relatedness with the regional knowledge base (Tanner 2014, 2015). Likewise, the descriptive findings for the H2FC industry by Madsen and Andersen (2010) suggest similar dynamics, as some of the industrial clusters located in the highly active $\mathrm{H} 2 \mathrm{FC}$ regions are defined by technologies that may underpin the development of $\mathrm{H} 2 \mathrm{FC}$.

While these studies focus on the development of new industries or technologies rather than new technologybased firms, or indeed green entry, it is possible to argue that the process of knowledge spillovers that defines such new firms may be also shaped by the recombination of locally embedded knowledge competencies, in a process of spatial path dependence. In this sense, regions whose innovation competencies are characterised by an increasing relatedness to environmental technologies may be more likely to generate knowledge spillovers and combinatorial opportunities along a similarly related technological trajectory, fostering green technological entry.

At the same time, as suggested by the literature on technological diversification, too much relatedness and cognitive proximity might lead to cognitive and technological lock-in (Nooteboom 2000; Boschma 2005). Regions that display greater technological diversification are characterised by the presence of a wider and heterogeneous pool of actors with different technological competencies. This may activate processes where diverse knowledge can overlap and interact (Storper 1995; Corradini and De Propris 2015). While some 
studies suggest a possible negative effect of unrelated variety on firm growth or the survival of new entrants (Neffke et al. 2014; Duschl 2016), the literature points to an important role of diversification in the early stages of a new industry, where knowledge from different industries may allow for more radical combinations (Henderson et al. 1995; Castaldi et al. 2014; Neffke et al. 2011). This might be the case also for green technologies.

Recent research on fuel cell industry indicates that the concept of technological relatedness may not be sufficient to explain the patterns of regional branching, showing that some regions entered the new industry despite previous economic activities not being technologically related to the emerging industry (Tanner 2014). These studies have mostly focused on new technologies. However, as novel associations of seemingly unrelated technological domains are usually driven by new innovators (Nelson and Winter 1982), the importance of diversification may equally extent to firms' technological entry. Evidence for this is offered by Corradini and De Propris (2015). Although they do not explicitly consider technological relatedness between the new firms and previous regional knowledge, they show that greater heterogeneity in the technological competencies available in regions may offer a broader set of combinatorial opportunities, generating processes of crossfertilisation across different technologies leading to the development of new innovating firms.

According to these arguments, we would expect regions characterised by technological activity related to environmental technologies to display a significant advantage in supporting the development of green new technology-based firms, as they provide a shared knowledge-base through which learning and communication is enhanced. However, extensive relatedness may generate cognitive lock-in, decreasing the potential for learning, as well as limit the set of opportunities for recombinations with other technology domains, gradually reducing the likelihood of green technological entry. In line with this, our third hypothesis is as follows:

Hypothesis 3: there is an inverted-U relationship between the level of relatedness to environmental technologies and green technological entry across regions.

\section{Data}

The analysis presented is based on patent data and regional economic statistics for over 900 NUTS3 regions across 15 European countries. ${ }^{1}$ The time period of reference of the study is defined by the patent applications whose priority date is between 1996 and 2006 included. Patent data are obtained from the PATSTATCRIOS database. ${ }^{2}$ Based on the PATSTAT database, which is developed by the World Intellectual Property Organisation (WIPO), together with OECD and Eurostat, the PATSTAT-CRIOS database offers detailed information on patent applications made at the most important patent offices worldwide, including the European Patent Office (EPO). In particular, the most relevant to our study is patent priority date, International Patent Classification (IPC) indicating the specific technological class of the patent and applicant data, such as cleansed and standardised company name and NUTS3 level location. ${ }^{3}$ In line with previous literature, patents that have been applied for by more than one applicant, also known as co-patents, have been associated with every applicant. In line with previous literature (Jaffe and Trajtenberg 2002; Breschi et al. 2010), patent applications are used in this study since they better capture the moment of knowledge creation allowing to be closer to the entry of new green technology-based companies.

Economic data at the regional level are obtained from the ESPON-Eurostat database. These include various socio-economic statistics that are mainly used as controls in the analysis, including GDP per capita, sectoral employment, total population and population density. These data are available for the time period from 1999 to 2006.

The use of patent data to measure eco-innovation is quite widespread in the literature (Wagner 2007, Arundel and Kemp 2009; Tanner 2015). They offer an objective indication of inventive output based on novelty and utility, and their strengths and weaknesses are well known (see Griliches 1990; Archibugi and Pianta 1996). For the specific case of green technologies, it is

\footnotetext{
$\overline{1}$ The countries analysed are: Austria, Belgium, Denmark, Germany, Spain, Finland, France, Greece, Italy, Ireland, Luxemburg, the Netherlands, Portugal, Sweden and the UK.

2 The PATSTAT-CRIOS database is developed and maintained by Bocconi University. For a detailed description, see Coffano and Tarasconi (2014).

${ }^{3}$ For specific details on the algorithm specifications on disambiguation, see Pezzoni et al. (2014).
} 
important to identify which patents can be considered environmentally beneficial (Arundel and Kemp 2009). To do so, and to build our measures of technological relatedness, we rely on the data on the IPC, based on the inventions' technical or scientific domain and/or destination of use. In particular, we adopt the reclassification of the IPC constituted by 30 different technological classes available through PATSTAT-CRIOS, which has been used extensively by previous studies on technological relatedness (see, for example, Breschi et al. 2003; Corradini and De Propris 2015), where one of the classes represents environmental technologies. This class includes patents on disposal of solid and water waste, reclamation of contaminated soil, waste heat recuperation, removal of combustion residues and purification of waste gases, among others. ${ }^{4}$

\section{Empirical specification}

\subsection{Dependent variable}

In this paper, we investigate empirically the emergence of green innovative new companies following an approach based on studies in evolutionary economics which focus on real technological entry rather than business entry as a proxy for new technology-based firms (Malerba and Orsenigo 1999; Corradini and De Propris 2015). Since our attention is on the formation of new and technology-based firms in the environmental sector, we define green technological entry as the occurrence of a new firm that applies for a patent for the first time, and whose subsequent innovations are mostly in environmental technologies.

PATSTAT-CRIOS database provides full coverage for the history of all patent applicants, allowing to keep track of companies' innovative activity over time ${ }^{5}$ and so identify the firms which apply for their first patent. To be considered green companies, the companies identified in the previous step need to have at least $50 \%$ of their inventions in the period of time observed classified as environmental technologies. As first patent may not always coincide with new firms, we add a further requirement to identify new green technology-based

\footnotetext{
${ }^{4}$ Specific classes included are: A62D, B01D-046-053, B09, C02, F01N, F23G and J. For more information on the concordance, see Schmoch (2008).

${ }^{5}$ This includes changes in patents ownership.
}

companies. Following Breschi et al. (2010), we only retain companies incorporated ${ }^{6}$ not earlier than 5 years from the first patent application.

As in the majority of regions, there is usually one such event per year, with less than $1 \%$ presenting a multiple entry, we define our dependent variable GREEN as a dichotomous variable being equal to 1 in the occurrence of green technological entry taking place within a NUTS3 region in a given year.

\subsection{Independent variables}

Knowledge spillovers from the innovative activities of incumbent firms constitute an essential driver on the entry of new innovative firms (Acs et al. 2009, 2013). To capture the importance of previous knowledge and technological path dependence in this process, we add to the model the accumulated total number of patent applications into a regional patent stock measure with the depreciation rate set at $15 \%$ (REGPSTOCK). This variable enters the model after being log transformed.

Significant variation in new firm creation remains even after accounting for the knowledge created within regions, pointing to different capabilities in the process of technological recombination embedded within informal institutions, companies and people across regions. To capture this, we include a variable (TECHENTRY) defined as the total count of new technological entrants across all sectors. Differently from our dependent variable, TECHENTRY does not necessarily imply the establishment of a new company, providing a more comprehensive proxy for the dynamism in technological entry within each region.

To capture the non-random pattern of technological activities that may link green technological entry to previous innovation within a region, we define an index of regional technological relatedness (RELATEDG) to measure the relatedness of the overall regional innovative activity with respect to environmental technologies. This index is based on the concept of knowledgerelatedness suggested by Breschi et al. (2003). In line with their approach, we start by calculating the knowledge-relatedness matrix whose elements are given by the cosine index $S_{\mathrm{ij}}$ that measures the similarity

\footnotetext{
${ }^{6}$ Data on incorporation dates are obtained from ORBIS, national company registers and companies' websites.
} 
between two technological classes $i$ and $j$ with respect to their relationship with all other IPC classes (see Breschi et al. 2003). Formally, we have:

$$
S_{\mathrm{ij}}=\frac{\sum_{k=1}^{30} C_{\mathrm{ik}} C_{\mathrm{jk}}}{\sqrt{\sum_{k=1}^{30} C_{\mathrm{ik}}^{2}} \sqrt{\sum_{k=1}^{30} C_{\mathrm{jk}}^{2}}}
$$

where $C_{\mathrm{ij}}$ represents the number of patents that have been classified in both technological classes $i$ and $j$ using information on all EPO patents between 1996 and 2006, for every $k$ IPC class. This process generates a $30 \times 30$ square matrix $M$ that can be used to measure knowledge-relatedness between patents in different classes. Thus, for every year $t$, we use the matrix $M$ to calculate an index $D_{\mathrm{rt}}$ measuring the technological distance between the IPC class of each patent in the $r_{\text {th }}$ region with respect to the class representing environmental technologies. Thus, the index RELATEDG $\mathrm{rr}_{\mathrm{rt}}$ for the $r_{\text {th }}$ region in year $t$ is calculated as the average value of all indices $D_{\mathrm{rt}}$ up to time $t$. To reflect our hypothesis of an inverted-U relationship between green technological entry and relatedness to environmental technologies in the regions, we also include a squared term for RELATEDG, which is expected to present a negative sign.

We also explore a different specification for the relationship between new knowledge creation and the relatedness across environmental and other technologies defining the variable PRELATEDG, which represents the number of new patents developed in the region weighted using the index of relatedness expressed in Eq. 1.
As controls, we add a second group of independent variables that are commonly employed in regional studies related to new firm creation. First, we add regions' GDP per capita in order to account for the size of the capital stock in the region. To measure human capital, we define the variable HCAP as the percentage on active population of the human resources employed in science and technology sectors. The variable MANUF, defined as the percentage of people working in manufacturing sectors over total employment, is added as proxy for the structural characteristics of the regions. We also include the total regional population (TOTPOP), in thousand people, to control for the size of each region and population density (PDENS), here defined as inhabitants per square kilometre. Densely populated areas can be associated with more intense interaction and higher productivity. In line with previous studies (Audretsch et al. 2010; Rodríguez-Pose and Hardy, 2015), this measure serves as a proxy for agglomeration and urbanisation economies not directly related to technological activity.

Finally, we include country and time dummies to respectively control for heterogeneity related to institutional, cultural and other unobserved determinants specific to each country, as well as common trends and fluctuations in economic and technological activity, such as business cycle effects.

\subsection{Model estimation}

In order to test our hypotheses, we model green technological entry as a function of the set of regional technology indicators while controlling for the socio-economic characteristics of the specific regions. We can formally define our empirical specification as follows:

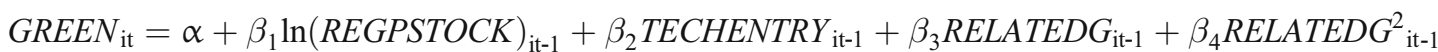

$$
\begin{aligned}
& +\beta_{5} \ln (\mathrm{GDP})_{\mathrm{it}-1}+\beta_{6} H C A P_{\mathrm{it}-1}++\beta_{7} M{ } A N U F_{\mathrm{it}-1}+\beta_{8} \text { TOTPOP }_{\mathrm{it}-1}+\beta_{9} P D E N S_{\mathrm{it}-1}+\delta_{\mathrm{it}}+\varepsilon
\end{aligned}
$$

where $\delta$ represents time and country dummies and $\varepsilon$ is the disturbance. All independent variables are lagged one period in order to reduce simultaneity problems.

As specified in Section 4.1, the dependent variable GREEN is defined as a dichotomous variable being equal to 1 for those regions $i$ experiencing the occurrence of green technological entry in year $t$, and 0 otherwise. Thus, we estimate a GLM regression model with a binomial distribution and logit link function via maximum likelihood. As regional relatedness tends to be relatively static across time, this approach is preferred to a fixed-effects specification relying solely on withinvariation. As the between region variation is considerably larger than the within region variation, this would lead to a substantial loss of information from the dataset. Also, for the observations that are not dropped, the limited within group variation is likely to lead to imprecise estimates and, thus large standard errors. 
Furthermore, the fixed-effects logit estimator is potentially inconsistent in the presence of serial correlation and heteroscedasticity (Wooldridge 2010), which are both a concern in the dataset. Instead, cluster robust standard errors are used in the GLM regression to account for potential heterogeneity and serial dependence over time. Results are fully robust to estimates ${ }^{7}$ obtained using generalised estimating equation (GEE) regression models (Liang and Zeger 1986), using a binomial distribution family and robust standard errors, which explicitly take into account the panel structure of the data exploiting both within and between variations while allowing to control for serial correlation (Hardin and Hilbe 2013).

\section{Results}

In this section, we first examine regional differences and spatial patterns in green technological entry. Looking at the data, it clearly emerges that the presence of green start-ups is not evenly distributed across regions and countries. The spatially limited and partially clustered nature of green technological entry is noticeable in Fig. 1a, where we report the distribution of these firms across NUTS 3 regions in the 15 countries examined.

Differences within countries are strong, with some areas presenting a prominently higher concentration of green technological entry. For example, the areas around Turin in northern Italy and Stuttgart in south-west Germany, but also Styria in Austria and Barcelona, present high entry levels which may be connected to the automotive industry. The area of Lazio in central Italy is instead connected to liquefied natural gas technologies. Again, Scandinavian capitals also perform well. In Fig. 1b, we observe the number of patents weighted by their relatedness to environmental technologies presents a visually similar distribution, offering initial evidence on the relationship between these two elements. With respect to the firms themselves, patent data indicate they are indeed technologically active. Half of them applied for more than one patent across the period considered, while around $16 \%$ hold more than five patents across an average window of activity of 4 years.

Descriptive statistics for our dataset are reported in Table 1, while Table 2 presents correlations for our variables. We note again that green technological entry

\footnotetext{
${ }^{7}$ Estimates are available upon request.
}

is a limited phenomenon in terms of geographical distribution, with only $5 \%$ of NUTS3 regions reporting some activity across the period considered. Similarly, regions seldom witness multiple entries per year, with less than $1 \%$ presenting more than one new green innovative company per year. Another important element that emerges is the well-known skewed distribution of innovative activities across Europe, which is mirrored by the statistics on patent stocks per region with a mean significantly higher than median value. Reflecting the connection between new knowledge creation and new innovative companies (Acs et al. 2009; Corradini and De Propris 2015), this skewness is also present for TECHENTRY. Looking at the RELATEDG, differences across regions are less marked. Yet, the relatedness between average regional activity and environmental technologies is mostly limited, with mean and median values equal to 10.11 and 8.28 , respectively.

Results for the GLM logit regression analysis are reported in Table 3. Columns 1 to 3 report the results with RELATEDG, which measures the average relatedness of patents developed within each NUTS3 region and environmental technologies, while columns 3 to 6 report PRELATEDG. We also report estimates with regional patent stock and technological entry defined in per capita terms, defined respectively REGPSTOCKpc and TECHENTRYpc, in columns 3 and 6. Given the nonlinear nature of the logit models, the estimates are expressed as odds ratios (ORs) ${ }^{8}$ to simplify their interpretation. In this sense, estimates higher than one indicate a positive effect and can be read as the percentage increase in the response variable for one unit increase in the regressor. Similarly, the independent variables present a negative effect when the corresponding odd ratios are less than one.

We first discuss the results for the technology-related variables. In the knowledge spillover theory of entrepreneurship (Acs et al. 2009, 2013), the cumulated stock of local knowledge in spatially bounded locations is considered a key determinant of new firm creation. In line with previous descriptive evidence (Madsen and Andersen 2010), our results confirm the importance of these dynamics for green new technology-based firms, as the number of patents developed in the region exerts a positive and statistically significant effect on green technological entry across all model specifications in Table 3. An exception to this is found in column 3, ${ }^{8}$ Odds are defined as the ratio of the probability of success over the
probability of failure. 


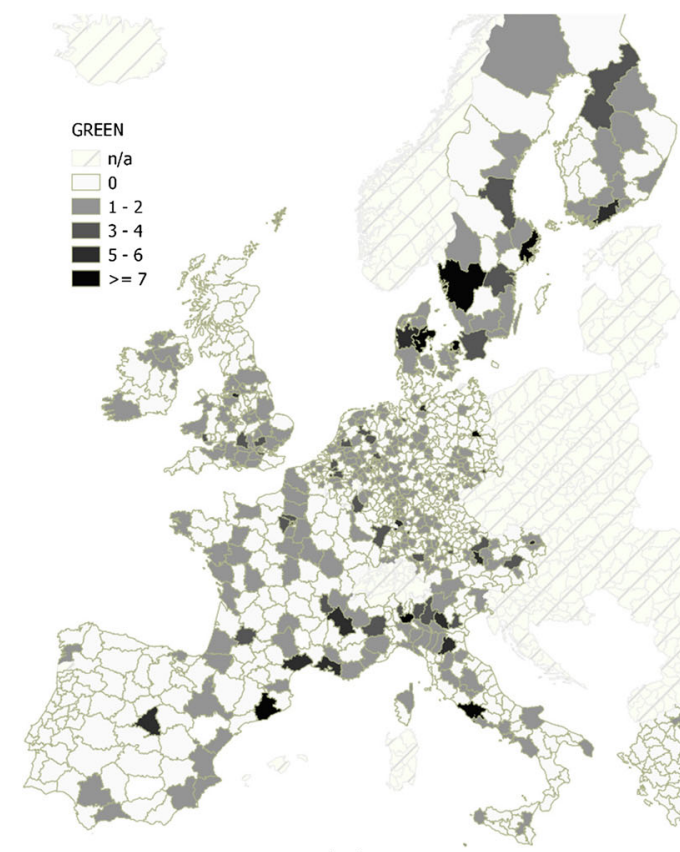

(a)

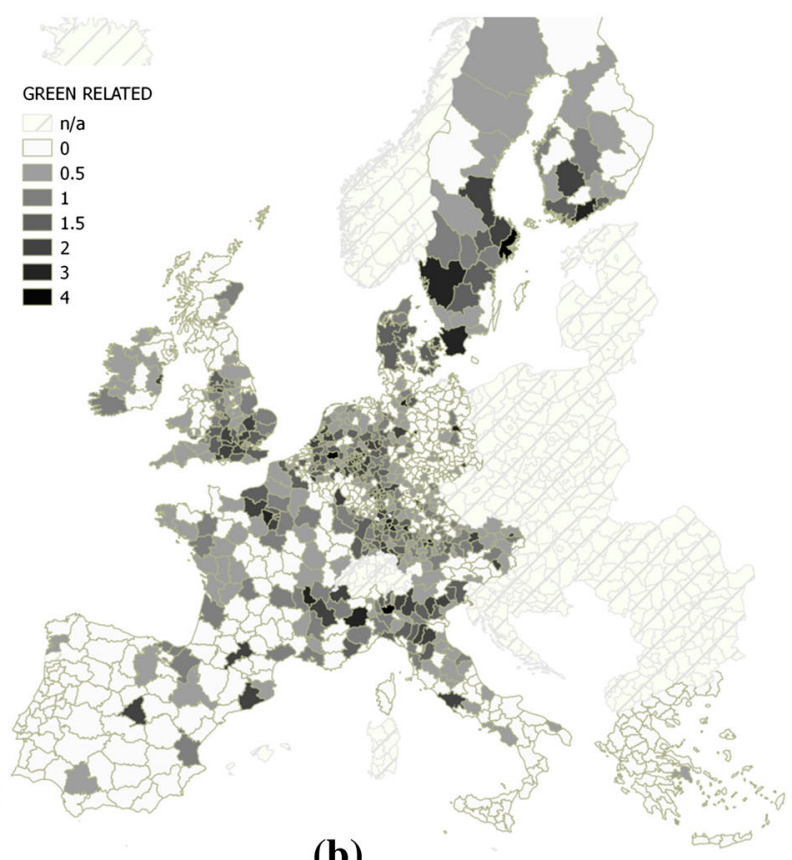

(b)

Fig. 1 a Green technological entry. b Green technological relatedness across NUTS3 regions 1996-2006

where regional patent stock is expressed in per capita terms. This suggests that the level of technological activity underlying processes of knowledge spillovers, rather than intensity, is an important determinant. Similarly, the importance of a more pronounced dynamism in technological entry is also found to provide a positive and significant role in the formation of new green innovators, as suggested by the estimates for TECHENTRY. This result holds when TECHENTRY is expressed in per capita terms.

To explore our third hypothesis, we look at the importance of path dependence in regional branching and the trade-off between relatedness and diversification with respect to environmental technologies for green technological entry. In the literature on evolutionary economic geography, regions are likely to evolve along technological trajectories that are related to their existing knowledge competencies (Martin and Sunley 2006; Neffke et al. 2011). In the same way, regions whose innovation activity is related to environmental technologies should enjoy an advantage in the creation of green start-ups. This is reflected by the estimates for the linear term of RELATEDG, which present a positive and significant effect, indicating that as the level of

Table 1 Descriptive statistics

\begin{tabular}{|c|c|c|c|c|c|}
\hline & Mean & Median & Max & Min & VIF \\
\hline GREEN & 0.05 & 0 & 1 & 0 & \\
\hline REGPSTOCK & 205 & 28 & 19,505 & 1 & 2.08 \\
\hline TECHENTRY & 4.74 & 2 & 128 & 0 & 2.16 \\
\hline RELATEDG & 10.11 & 8.28 & 100 & 0.74 & 1.05 \\
\hline GDP & $24,696.32$ & $23,041.34$ & $164,575.70$ & $8,353.08$ & 1.92 \\
\hline EDUC & 35.33 & 35.6 & 58.9 & 8.5 & 1.36 \\
\hline MANUF & 29.66 & 29.66 & 45.21 & 10.28 & 1.20 \\
\hline ТОТРОР & 400.81 & 250.80 & 5705.62 & 19.21 & 1.89 \\
\hline PDENS & 566.20 & 189.14 & $20,511.69$ & 1.90 & 1.34 \\
\hline
\end{tabular}


Table 2 Correlation matrix

\begin{tabular}{|c|c|c|c|c|c|c|c|c|}
\hline & 1 & 2 & 3 & 4 & 5 & 6 & 7 & 8 \\
\hline GREEN & 1 & & & & & & & \\
\hline REGPSTOCK & 0.157 & 1 & & & & & & \\
\hline TECHENTRY & 0.294 & 0.528 & 1 & & & & & \\
\hline RELATEDG & 0.163 & -0.107 & -0.069 & 1 & & & & \\
\hline GDP & 0.134 & 0.601 & 0.406 & -0.070 & 1 & & & \\
\hline EDUC & 0.073 & 0.374 & 0.192 & -0.031 & 0.383 & 1 & & \\
\hline MANUF & -0.068 & 0.006 & -0.124 & 0.013 & -0.044 & -0.224 & 1 & \\
\hline ТОТРОР & 0.198 & 0.349 & 0.607 & -0.050 & 0.109 & -0.012 & -0.240 & 1 \\
\hline PDENS & 0.117 & 0.310 & 0.359 & -0.018 & 0.424 & 0.222 & -0.193 & 0.265 \\
\hline
\end{tabular}

technological relatedness with respect to environmental innovations increases, regions present a higher likelihood of green technological entry. Yet, our results also seem to support the idea that extensive relatedness in a specific sector, in this case environmental technologies, may lead to reduced cross-fertilisation across different technologies decreasing the potential for learning and recombinant innovation connected to green technological entry (Boschma 2005; Corradini and De Propris 2015), with the quadratic term of RELATEDG presenting a negative and statistically significant effect. In line with our hypothesis, these findings indicate the presence of an inverted-U relationship between RELATEDG and green technological entry. Interestingly, models ${ }^{9}$ with only a linear term do not yield significant coefficients for RELATEDG, providing further evidence for the inverted-U relationship identified through the quadratic term.

We further explore this hypothesis using an alternative measure for regional relatedness with respect to environmental technologies. Columns 3 to 6 present the results using PRELATEDG. To avoid multicollinearity, REGPSTOCK is excluded from these models. As for the previous specification, we find significant estimates pointing to an inverted-U relationship between this variable and GREEN. This is particularly interesting, as it further underlines the importance of the relationship between new knowledge creation and the relatedness across environmental and other technologies. In other words, as the connection between the number of innovations developed and their closeness to environmental technologies increases, opportunities for green technological entry are likely to increase. However, there are diminishing returns

\footnotetext{
${ }^{9}$ Estimates are available upon request.
}

to this effect, as stronger specialisation across a narrower technological landscape also reduces potential crossfertilisation across different technologies, a process which is more connected to the emergence of new technologybased firms (Corradini and De Propris 2015).

Looking at the control variables, we observe a positive and significant effect for GDP across the different model specifications. Instead, the estimates for both HCAP and MANUF, as well as PDENS are not statistically significant. Our control for the size of the region, TOTPOP, is significant and positive reflecting the fact that larger regions predictably support a wider amount of economic and innovative activity.

\section{Conclusions}

This paper contributes to the research on green entrepreneurship providing novel empirical evidence on the spatial distribution and the location determinants of green technological entry. In particular, we study the role played by the specific characteristics of the regional technological activity and knowledge base focusing on the importance of the cumulated stock of local knowledge by incumbent companies, the presence of dynamism in technological entry in the region and the relationship between regional technological relatedness and knowledge spillovers as potential sources of green technological entry.

Exploring a dataset covering over 900 NUTS3 regions over 15 European countries obtained merging economic data from ESPON-Eurostat and patent information from the PATSTAT-CRIOS database for the period 1996-2006, we find that the distribution of green 
Table 3 GLM logit regression estimates

GLM logit

(1)

$\begin{array}{ll}1.148 * * & 1.155^{* * *} \\ (0.063) & (0.064) \\ 1.025 * * * & 1.026^{* * *} \\ (0.007) & (0.007)\end{array}$

REGPSTOCKpc

TECHENTRYpc

RELATEDG

RELATEDG $^{\wedge} 2$

PRELATEDG

PRELATEDG` $^{\wedge}$

GDP

EDUC

MANUF

TOTPOP

PDENS

Constant

Obs

Regions

Log-pseudolikelihood

$$
\begin{aligned}
& 1.840 * * \\
& (0.509)
\end{aligned}
$$

$1.048 * *$

(0.022)

$0.997 *$

(0.002)$$
(0.509)
$$

(2) (3)

(3)

(4)

(5)

(6)

$1.185 * * *$

(0.051)

$\begin{array}{ll}1.026 * * * & 1.027 * * * \\ (0.007) & (0.007)\end{array}$

1.043

(0.176)

$1.246 * * *$

(0.052)

$1.043 * *$

(0.021)

$0.997 *$

(0.002)

$\begin{array}{ll}1.048 * * & 1.043 * * \\ (0.022) & (0.021) \\ 0.997 * & 0.997 * \\ (0.002) & (0.002)\end{array}$

$\begin{array}{lll}1.833 * * * & 1.881 * * * & 1.768 * * * \\ (0.233) & (0.245) & (0.231) \\ 0.856^{* * *} & 0.853 * * * & 0.901 * * \\ (0.048) & (0.049) & (0.040) \\ 1.637 * & 1.677 * & 1.557 * \\ (0.448) & (0.462) & (0.415) \\ & 0.988 & 0.992 \\ & (0.016) & (0.016) \\ & 0.989 & 0.991 \\ & (0.014) & (0.013) \\ 1.000 * * * & 1.000 * * * & 1.001 * * * \\ (0.000) & (0.000) & (0.000) \\ 1.000 & 1.000 & 1.000 \\ (0.000) & (0.000) & (0.000) \\ 0.000^{* * *} & 0.000 * * * & 0.000 * * * \\ (0.000) & (0.001) & (0.001) \\ 5779 & 5779 & 5779 \\ 923 & 923 & 923 \\ -1007.30 & -1006.90 & -1007.83 \\ & & \end{array}$

All regressions include time and country dummies

$* p \leq 0.10 * * p \leq 0.05 * * * p \leq 0.01$ - coefficients reported as odd ratios (ORs) - cluster robust SE reported

technological entry is uneven across and within countries, and it is strongly defined by spatial path dependence. Our results indicate that regions characterised by higher levels of innovative activity provide more opportunities for recombination through the provision of knowledge spillovers, while those defined by a more persistent and dynamic emergence of new technological companies are more likely to present higher capabilities to absorb and act upon technological opportunities. In this way, they may also foster green technological entry.

We also find evidence of an inverted- $U$ relationship between regional technological relatedness and green technological entry. In this sense, regions characterised by technological activities related to environmental technologies offer a significant advantage in supporting the development of green NTBFs, as they provide a 
shared knowledge-base through which learning and communication are enhanced. However, our results also indicate that extensive relatedness may limit the set of opportunities for recombinations with other technology domains, gradually reducing the likelihood of green technological entry.

Results from the paper need to be interpreted considering some potential limitations of the research. In particular, the use of patent data may offer only a partial picture of environmental innovation activities, as not all innovations are patented by companies and process innovations are not covered. In this sense, evidence on green technological entry may not necessarily extend to the broader group of green innovative start-ups. Furthermore, notwithstanding the use of lagged predictor variables and patent stock measure as independent variable to reduce potential endogeneity in the analysis, further studies may be required to shed more definite light on the causal relationships in our findings. These elements constitute the next step in our research.

Open Access This article is distributed under the terms of the Creative Commons Attribution 4.0 International License (http:// creativecommons.org/licenses/by/4.0/), which permits unrestricted use, distribution, and reproduction in any medium, provided you give appropriate credit to the original author(s) and the source, provide a link to the Creative Commons license, and indicate if changes were made.

\section{References}

Acs, Z. J., \& Audretsch, D. B. (1987). Innovation, market structure and firm size. Review of Economics and Statistics, 69, 567575.

Acs, Z. J., Braunerhjelm, P., Audretsch, D. B., \& Carlsson, B. (2009). The knowledge spillover theory of entrepreneurship. Small Business Economics, 32, 15-30.

Acs, Z. J., Audretsch, D. B., \& Lehmann, E. E. (2013). The knowledge spillover theory of entrepreneurship. Small Business Economics, 41, 757-774.

Antonioli, D., Mancinelli, S., \& Mazzanti, M. (2013). Is environmental innovation embedded within high-performance organisational changes? The role of human resource management and complementarity in green business strategies. Research Policy, 42, 975-988.

Aragón-Correa, J. A., Hurtado-Torres, N., Sharma, S., \& GarcíaMorales, V. J. (2008). Environmental strategy and performance in small firms: a resource-based perspective. Journal of Environmental Management, 86, 88-103.

Archibugi, D., \& Pianta, M. (1996). Measuring technological change through patents and innovation surveys. Technovation, 16, 451-468.
Armington, C., \& Acs, Z. J. (2002). The determinants of regional variation in new firm formation. Regional Studies, 36, 33- 45.

Arundel, A., \& Kemp, R. (2009). Measuring eco-innovation. UNU-MERIT Working Paper Series 017.

Audretsch, D. B., \& Feldmann, M. (1996). R\&D spillovers and the geography of innovation and production. American Economic Review, 86, 630-640.

Audretsch, D. B., \& Lehmann, E. E. (2005). Does the knowledge spillover theory of entrepreneurship hold for regions? Research Policy, 34, 1191-1202.

Audretsch, D. B., Keilbach, M., \& Lehmann, E. (2006). Entrepreneurship and economic growth. New York: Oxford University Press.

Audretsch, D., Dohse, D., \& Niebuhr, A. (2010). Cultural diversity and entrepreneurship: a regional analysis for Germany. The Annals of Regional Science, 45(1), 55-85.

Bansal, P., \& Hoffman, A. J. (2012). The Oxford handbook of business and the natural environment. Oxford: Oxford University Press.

Bathelt, H., \& Glückler, J. (2003). Toward a relational economic geography. Journal of Economic Geography, 3, 117-144.

Beugelsdijk, S., \& Noorderhaven, N. (2004). Entrepreneurial attitude and economic growth: a cross-section of 54 regions. The Annals of Regional Science, 38, 199-218.

Boschma, R. (2005). Proximity and innovation: a critical assessment. Regional Studies, 39, 61-74.

Boschma, R. A., \& Frenken, K. (2006). Why is economic geography not an evolutionary science? Towards an evolutionary economic geography. Journal of Economic Geography, 6, 273-302.

Boschma, R., \& Martin, R. (2010). Handbook of evolutionary economic geography. Cheltenham: Edward Elgar.

Breschi, S., Lissoni, F., \& Malerba, F. (2003). Knowledgerelatedness in firm technological diversification. Research Policy, 32, 69-87.

Breschi, S., Malerba, F., \& Mancusi, M. L. (2010). Survival of innovative entrants in knowledge-based sectors. In F. Malerba (Ed.), Knowledge intensive entrepreneurship and innovation systems: evidence from Europe (pp. 136-153). Abingdon: Routledge.

Carraro, C., \& Siniscaico, D. (1994). Environmental policy reconsidered: the role of technological innovation. European Economic Review, 38, 545-554.

Castaldi, C., Frenken, K., \& Los, B. (2014). Related variety, unrelated variety and technological breakthroughs: an analysis of US state-level patenting. Regional Studies. https://doi. org/10.1080/00343404.2014.940305.

Coffano, M, \& Tarasconi, G. (2014). CRIOS-Patstat database: sources, contents and access rules. Center for Research on Innovation, Organization and Strategy, CRIOS Working Paper n.1.

Cohen, W. M., \& Levinthal, D. A. (1990). Absorptive capacity: a new perspective on learning and innovation. Administrative Science Quarterly, 35, 128-152.

Cooke, P. (2010). Jacobian cluster emergence: wider insights from 'green innovation' convergence on a Schumpeterian 'failure'. In Emerging clusters: theoretical, empirical and political perspectives in the initial stage of cluster evolution (pp. 1742). Cheltenham: Edward Elgar. 
Cooke, P., \& Morgan, K. (1998). The associational economy. firms, regions, and innovation. Oxford: Oxford University Press.

Corradini, C., \& De Propris, L. (2015). Technological diversification and new innovators in European regions: evidence from patent data. Environment and Planning A, 47(10), 2170-2186.

Corradini, C., Demirel, P., \& Battisti, G. (2016). Technological diversification within UK's small serial innovators. Small Business Economics, 47, 163-177.

Criscuolo, C., \& Menon, C. (2015). Environmental policies and risk finance in the green sector: cross-country evidence. Energy Policy, 83, 38-56.

Demirel, P., \& Kesidou, E. (2011). Stimulating different types of eco-innovation in the UK: government policies and firm motivations. Ecological Economics, 70, 1546-1557.

Duschl, M. (2016). Firm dynamics and regional resilience: an empirical evolutionary perspective. Industrial and Corporate Change, 25(5), 867-883.

Ejermo, O., \& Xiao, J. (2014). Entrepreneurship and survival over the business cycle: how do new technology-based firms differ? Small Business Economics, 43(2), 411-426.

European Commission. (2010). SMEs and the environment in the European Union. Luxembourg: Publications Office of the European Union.

Frenken, K., Van Oort, F., \& Verburg, T. (2007). Related variety, unrelated variety and regional economic growth. Regional Studies, 41, 685-697.

Fritsch, M., \& Mueller, P. (2007). The persistence of regional new business formation-activity over time-assessing the potential of policy promotion programs. Journal of Evolutionary Economics, 17, 299-315.

Garud, R., \& Karnøe, P. (2003). Bricolage versus breakthrough: distributed and embedded agency in technology entrepreneurship. Research Policy, 32, 277-300.

Glaeser, E. L., Kallal, H., Scheinkman, J., \& Shleifer, A. (1992). Growth in cities. Journal of Political Economy, 100, 11261152.

Griliches, Z. (1990). Patent statistics as economic indicators: a survey. Journal of Economic Literature, 28, 1661-1707.

Hall, J. K., Daneke, G. A., \& Lenox, M. J. (2010). Sustainable development and entrepreneurship: past contributions and future directions. Journal of Business Venturing, 25, 439448.

Hardin, J. W., \& Hilbe, J. M. (2013). Generalized estimating equations (2nd ed.). London: Chapman and Hall.

Henderson, V., Kuncoro, A., \& Turner, M. (1995). Industrial development in cities. The Journal of Political Economy, 103, 1067-1090.

Hockerts, K., \& Wüstenhagen, R. (2010). Greening Goliaths versus emerging Davids - theorizing about the role of incumbents and new entrants in sustainable entrepreneurship. Journal of Business Venturing, 25, 481-492.

Hoogendoorn, B., Guerra, D., \& van der Zwan, P. (2015). What drives environmental practices of SMEs? Small Business Economics, 44, 759-781.

Horbach, J. (2008). Determinants of environmental innovationnew evidence from German panel data sources. Research Policy, 37, 163-173.

Jacobs, J. (1969). The economy of cities. New York: Vintage.
Jaffe, A. B., \& Trajtenberg, M. (2002). Patents, citations, and innovations: a window on the knowledge economy. Cambridge: MIT press.

Jaffe, A. B., Trajtenberg, M., \& Henderson, R. (1993). Geographic localization of knowledge spillovers as evidenced by patent citations. The Quarterly Journal of Economics, 108, 577598.

Jaffe, A. B., Newell, R. G., \& Stavins, R. N. (2003). Technological change and the environment. Handbook of Environmental Economics, 1, 461-516.

Kesidou, E., \& Demirel, P. (2012). On the drivers of eco-innovations: empirical evidence from the UK. Research Policy, 41, 862-870.

Klepper, S. (1996). Entry, exit, growth, and innovation over the product life cycle. The American Economic Review, 86, 562583.

Lehmann, M. (2006). Government-business relationships through partnerships for sustainable development: the green network in Denmark. Journal of Environmental Policy and Planning, $8,235-257$.

Liang, K., \& Zeger, S. (1986). Longitudinal data analysis using generalized linear models. Biometrika, 73, 13-22.

Lucas, R. E. (1993). Making a miracle. Econometrica: Journal of the Econometric Society, 61, 251-272.

Madsen, A. N., \& Andersen, P. D. (2010). Innovative regions and industrial clusters in hydrogen and fuel cell technology. Energy Policy, 38, 5372-5381.

Malerba, F., \& Orsenigo, L. (1999). Technological entry, exit and survival: an empirical analysis of patent data. Research Policy, 28, 643-660.

Mans, P., Alkemade, F., van der Valk, T., \& Hekkert, M. P. (2008). Is cluster policy useful for the energy sector? Assessing selfdeclared hydrogen clusters in the Netherlands. Energy Policy, 36, 1375-1385.

Marshall, A. (1890). Principles of economics. London: MacMillan.

Martin, R., \& Sunley, P. (2006). Path dependence and regional economic evolution. Journal of Economic Geography, 6, 395-437.

Maurseth, P., \& Verspagen, B. (2002). Knowledge spillovers in Europe: a patent citations analysis. Scandinavian Journal of Economics, 104, 531-545.

Meyskens, M., \& Carsrud, A. L. (2013). Nascent greentechnology ventures: a study assessing the role of partnership diversity in firm success. Small Business Economics, 40, 739-759.

Moreno, R., Paci, R., \& Usai, S. (2005). Spatial spillovers and innovation activity in European regions. Environment and Planning A, 37, 1793-1812.

Neffke, F., Henning, M., \& Boschma, R. (2011). How do regions diversify over time? Industry relatedness and the development of new growth paths in regions. Economic Geography, $87,237-265$.

Neffke, F., Hartog, M., Boschma, R. \& Henning, M. (2014). Agents of structural change: the role of firms and entrepreneurs in regional diversification. Papers in Evolutionary Economic Geography, no. 14.10, Utrecht University, Utrecht.

Nelson, R. R., \& Winter, S. (1982). An evolutionary theory of economic change. Cambridge: Belknap Press. 
Nooteboom, B. (2000). Learning and innovation in organizations and economies. Oxford: Oxford University Press.

OECD. (2011). Better Policies to Support Eco-innovation. OECD Publishing: OECD Studies on Environmental Innovation.

Pezzoni, M., Lissoni, F., \& Tarasconi, G. (2014). How to kill inventors: testing the Massacrator $\odot$ algorithm for inventor disambiguation. Scientometrics, 101, 477-504.

Popp, D., Newell, R. G., \& Jaffe, A. B. (2010). Energy, the environment, and technological change. Handbook of the Economics of Innovation, 2, 873-937.

Rehfeld, K. M., Rennings, K., \& Ziegler, A. (2007). Integrated product policy and environmental product innovations: an empirical analysis. Ecological Economics, 61, 91-100.

Rogers, M. (2004). Networks, firm size and innovation. Small Business Economics, 22(2), 141-153.

Romer, P. M. (1990). Endogenous technological change. The Journal of Political Economy, 98, 71-102.

Rothwell, R. (1989). Small firms, innovation and industrial change. Small Business Economics, 1(1), 51-64.

Rodríguez-Pose, A., \& Hardy, D. (2015). Cultural diversity and entrepreneurship in England and Wales. Environment and Planning A, 47(2), 392-411.

Saxenian, A. (1990). Regional networks and the resurgence of Silicon Valley. California Management Review, 33, 89-111.

Schmoch, U. (2008). Concept of a technology classification for country comparisons. Final report to the World Intellectual Property Organisation (WIPO). http://www.wipo. int/edocs/mdocs/classifications/en/ipc_ce_41/ipc_ce_41_5annex1.pdf.

Smith, A. (2007). Emerging in between: the multi-level governance of renewable energy in the English regions. Energy Policy, 35, 6266-6280.
Sonn, J. W., \& Storper, M. (2008). The increasing importance of geographical proximity in knowledge production: an analysis of US patent citations, 1975-1997. Environment and Planning A, 40, 1020-1039.

Storey, D. J., \& Tether, B. S. (1998). New technology-based firms in the European Union: an introduction. Research Policy, 26(9), 933-946.

Storper, M. (1995). The resurgence of regional economies, ten years after: the region as a nexus of untraded interdependences. European Urban and Regional Studies, 2, 191-221.

Tanner, A. N. (2014). Regional branching reconsidered: emergence of the fuel cell industry in European regions. Economic Geography, 90, 403-427.

Tanner, A.N. (2015). The emergence of new technology-based industries: the case of fuel cells and its technological relatedness to regional knowledge bases. Journal of Economic Geography, 16(3), 611-635..

Triguero, A., Moreno-Mondéjar, L., \& Davia, M. A. (2013). Drivers of different types of eco-innovation in European SMEs. Ecological Economics, 92, 25-33.

Wagner, M. (2007). On the relationship between environmental management, environmental innovation and patenting: evidence from German manufacturing firms. Research Policy, 36, 1587-1602.

Wagner, M. (2008). Empirical influence of environmental management on innovation: evidence from Europe. Ecological Economics, 66, 392-402.

Wooldridge, J. M. (2010). Econometric analysis of cross section and panel data (2nd ed.). Cambridge: MIT Press.

Ziegler, A., \& Nogareda, J. S. (2009). Environmental management systems and technological environmental innovations: Exploring the causal relationship. Research Policy, 38, 885-893. 